\title{
Development of Digital Learning Media for Renewable Energy Subject Based on Concepts Understanding of Electrical Engineering Department's Students State University of Malang
}

\author{
Yuni Rahmawati ${ }^{1 *}$ David Anggara Putra ${ }^{2 *}$ Siti Sendari $^{3^{*}}$ Wahyu Sakti $^{4^{*}}$ Toru Matsumoto $^{5}$ \\ *Corresponding author Email : yuni.rahmawati.ft@um.ac.id, davidanggaragara@gmail.com, siti.sendari.ft@um.ac.id, \\ wahyu.sakti.ft@um.ac.id
}

\begin{abstract}
The aims of this research and development are: (1) Designing and Building digital learning media for renewable energy; (2) Designing and buliding simulations based on concepts understanding renewable energy; (3) Evaluating the feasibility of digital learning media and simulation Renewable Energy.

This development uses the ADDIE research model with 5 stages of research and development. The Validation of digital media and simulation for teaching materials of Renewable Energy was conducted by 2 (two) Electrical Engineering Expertise. The feasibility evaluating of digital learning media and simulation using questionnaire instrument conducted by 33 electrical engineering students.

The results showed that validation of digital learning media and simulation of renewable energy obtained a percentage of $83.4 \%$ from 2 (two) expert lecturers, that mean the product was suitable for use with a slight revision. And for the feasibility of digital learning media and simulation Renewable Energy gotten $86 \%$ that means the product is very feasible to use without any further revisions.

The conclusion of this research and development is proven that the digital learning media and simulation of renewable energy is very feasible to use. Digital learning media and simulation of Renewable Eneregy are also able to provide undergraduate students with an understanding of the concept of electricity generation systems for renewable energy plants.
\end{abstract}

Keywords: digital learning media, simulation, concept understanding, renewable energy

\section{INTRODUCTION}

Today the use of renewable energy is a major issue in various countries, the aim is maintaining energy sustainability. The use of renewable energy is very important for sustainable systems, because the nature of renewable energy can be used in a long time span and is easily obtained without waiting for a long time (EBTKE, 2016). While in Indonesia itself has begun to aggressively utilize renewable energy to maintain the composition of the energy mix of the power plant remains optimal. This effort was taken through the ratification of the Electricity Supply Business Plan (RUPTL) of PT. State Electric Company (PLN) Persero 2018-2027. In the RUPTL, the government has set a target of generating energy mix until the end of 2025 for New
Renewable Energy (EBT) from $12.4 \%$ to $23.0 \%$ (ESDM, 2018).

Along with the increasing use of new and renewable energy in the field of electricity generation, human resource regeneration is needed to manage it. Regeneration of human resources can be done through the education system to achieve a certain expertise or competency. In its application, education requires several learning tools to be able to work, including media and teaching materials that can be used as a means to understand the concepts of competencies or skills learned.

Understanding comes from the word "understanding" which, according to the Big Indonesian Dictionary (KBBI) means to understand correctly. Meanwhile, according to Smith (2008) 
the concept is knowledge gained from previous learning experiences, reading books, the internet, and experiences in the environment. So it can be concluded that understanding the concept is a true understanding of the knowledge gained from experience during his life. The concept of planning the installation renewable energy sources into the electrical energy network is used to see the reliability of a network system. In planning the installation of new and renewable energy sources into the electricity grid, load flow analysis is used. Load flow analysis is important for planning, operating economics, scheduling and changing utility power (Divya, 2007).

One of the subjects that studies about the installation and generation of renewable energy sources is Renewable Energy course in Electrical Engineering Department, State University of Malang. Competency standards that must be mastered by students include being able to clarify the working principles of the conversion of new and renewable energy in terms of technical, economic, financial, sociocultural and environmental aspects. From the results of interviews with lecturers supporting Renewable Energy course in December 2018, it can be concluded the problems in the learning process is the unavailability of instructional digital media and simulation to support ongoing learning activities.

\section{RESEARCH METHODS}

This research and development is useful for developing teaching materials as digital media and simulation that can be used to support the learning process on Renewable
Energy subject. Besides being able to be used in the classroom, this digital learning media and simulation can be used outside the classroom as a source of independent learning for students. Not only that, this digital learning media can also be used in other subjects that have the same or related material, such as Distributed Generating System, Power System Transmission and Distribution and Analysis Systems which are also taken by Electrical and Electrical Engineering students. The use of digital learning media and simulation makes it easier for students to understand material about the power distribution system in renewable energy power plants because students will be introduced to each of their components even though in virtual form, and can make adjustments independently with digital module guidance.

The research and development model used to develop digital learning media is the ADDIE research and development model. The model was chosen as the basis for developing this digital learning media product because of its systematic steps in accordance with the needs to be used, as well as good and flexible rules for use in developing digital learning media for power distribution systems in new and renewable energy power plants.

The ADDIE research and development model consists of 5 stages, namely: (1) Analysis of media needs in learning the New and Renewable Energy course; (2) Learning media design in the form of digital media as a modules and simulation of renewable energy sources; (3) Development of digital modules and simulation of renewable energy sources; (4) Implementation of digital modules and simulation of renewable energy sources; (5) Evaluation of producs

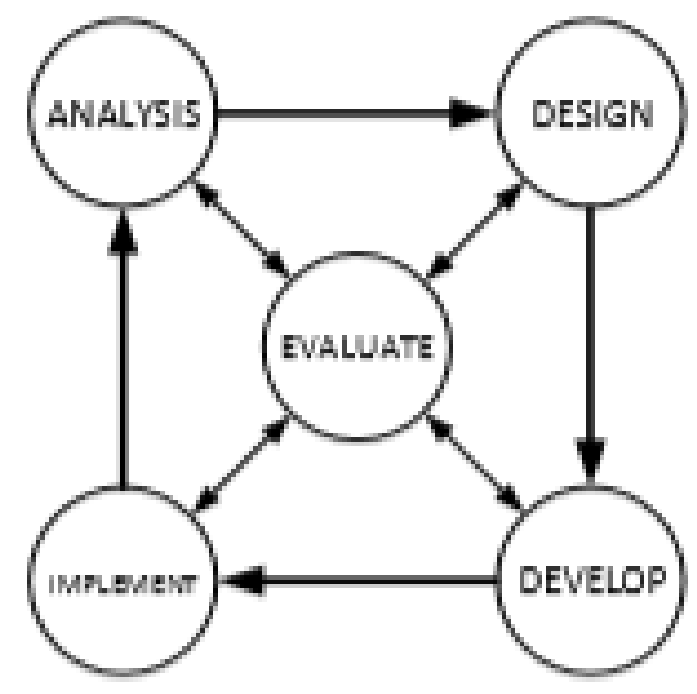

Fig 1. ADDIE Research and Development Model 
Research procedures with the ADDIE model:

\section{Analysis}

Analysis is an initial step in the procedure for developing ADDIE. The first step taken direct interview to 15 students randomly who have taken Renewable Energy course to find out the potential and problems that occur in the learning process. In addition to students, observations were also made to lecturers supporting Renewable Energy course. Through observations made it is expected to get a discription of the situation that has been happening, what media have been used and the appropriate learning process used in the course of Renewable Energy.

Through observations from undergraduate students, learning activities still contain lectures referrences, discussions, assignments and presentations. In other side this course need many tools and device to implemented, and need a long time and many source to make real to make student understand about compehensive content . The solution is building digital learning media learning media so that learning activities are more understanding and interesting. This media can be used for independent learning, in every time and every place to reduce the factors that is less than a maximum of students in understanding the material presented.
In addition to the problems or constraints as explained above, from interviews and observations, there is a potential that there are LCD projectors in every class in the Department of Electrical Engineering, State University of Malang. Thus it is possible to display digital learning media through the projector's LCD. Another potential is that lecturers and all Electrical Engineering undergraduate students have a personal laptop so that digital learning media can be operated with their respective laptops.

\section{Design}

Some of the activities carried out at the design stage include digital module and simulator design design. Each design phase is explained as follows:

\section{Digital Module Design}

To simplify the process of developing this teaching material, the flow structure and story board of the teaching module will be made. The flow structure is made to facilitate the design of the flow of the program in the teaching module to be developed. The flow structure of the digital module to be developed can be seen in Figure 2

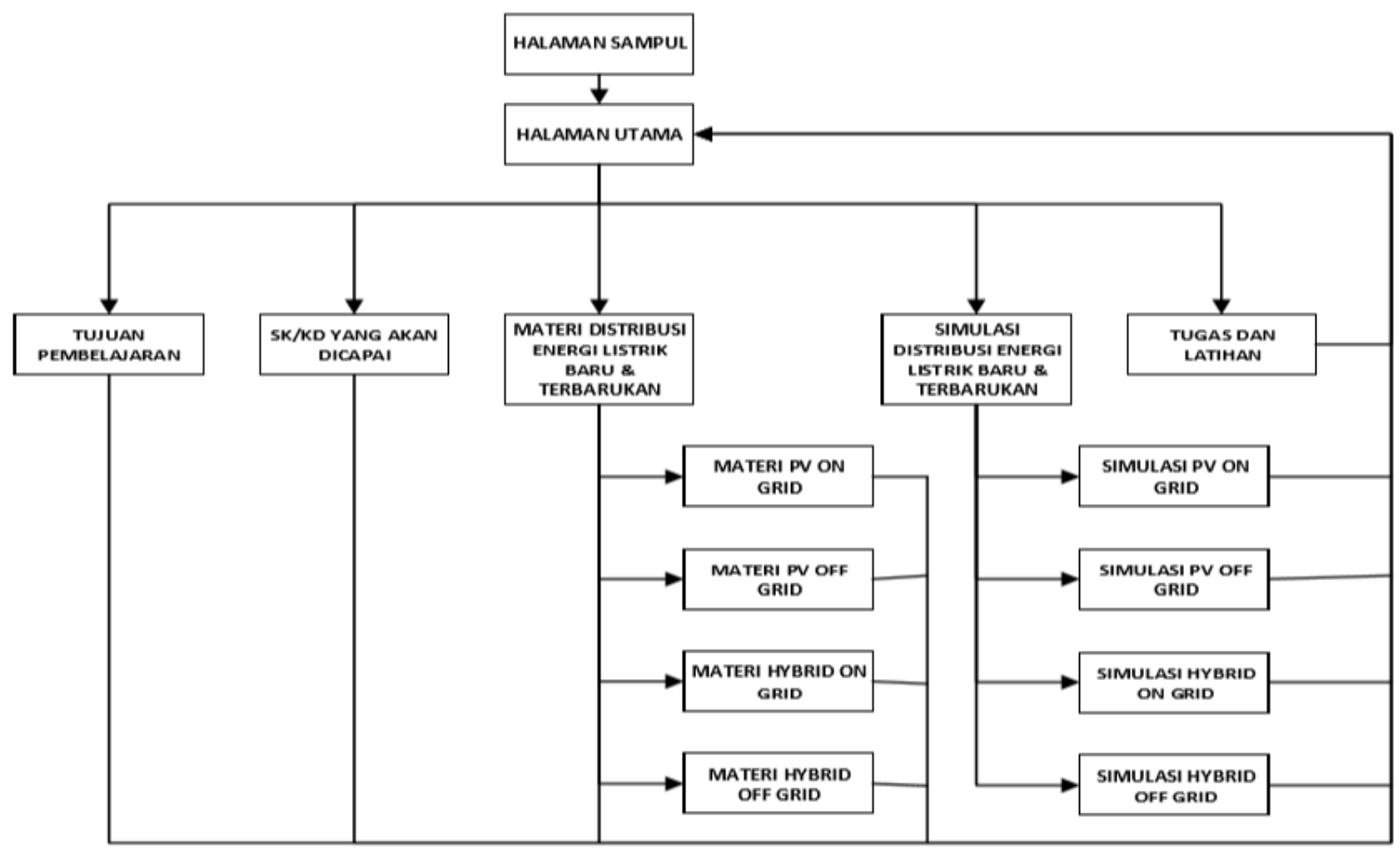

Figure 2 


\section{Simulator Design}

In designing or designing electric power distribution system simulators in power plants with new and renewable energy sources using ETAP 12.6.0 software. ETAP 12.6.0 software is used as a media in making series as well as a media setting circuit.

\section{Develop}

At the development stage, after the design was validated by Expert I and Expert II, a digital module design was realized in the form of a file with the extension .exe, and a simulator in the form of a single line diagram program in the ETAP 12.6.0 application. Research and development of digital learning media on the power distribution system in new and renewable energy power plants is expected to be able to support the learning process in the future so that students will have a better understanding level going forward. In solar power plants the electricity produced is direct current (DC) electricity, whereas electricity from the PLN network itself is alternating current electricity (AC). For this reason, several additional devices are needed so that the electrical energy produced by solar power plants can be connected to the PLN grid.

\section{Implementation}

At this implementation stage digital learning media that has been validated by expert 1 and expert 2 will be applied directly into learning. After being validated, it can be ascertained that digital learning media for the distribution of electric power systems in new and renewable energy power plants can be used as learning media. To test the feasibility of digital learning media implementation is carried out with classroom learning activities. This implementation activity is carried out by preparing digital modules and simulators as learning media.

At this stage, digital learning media for the distribution system of electricity in new and renewable energy power plants will be implemented to students of the Electrical Engineering study program class of 2016 with a strong current concentration in the Department of Electrical Engineering, State University of Malang, who is taking a New and Renewable Energy course.

\section{Evaluate}

Evaluation is a process to see whether the stages that have been taken in the 4 (four) stages of the ADDIE model above have reached the limits of eligibility or not. If there are deficiencies or discrepancies, there will be revisions to each of these stages. The results of the analysis are then used as consideration for developing a product. At the design stage, an evaluation is carried out taking into account expert opinions about the design being developed. The evaluation phase is also at the development stage, carried out by developing a form of instructional media. Then in the implementation phase, the evaluation phase is carried out by assessing the products developed, looking for deficiencies that can be fixed and making improvements. So at every stage there is always an evaluation.

\section{Validation and Trial Techniques}

The validation and trial or product evaluation techniques in this research and development are carried out in 3 (three) stages, namely product validation by experts, small group trials and large group trials. The results of the validation and trial are intended to collect data related to and lack of teaching materials. The three stages are explained as follows.

\section{a. Expert Validation}

In the product validation stage, the experts involved 2 (two) validators, lecturers as expert judment. This evaluation aims to assess the appropriateness of the contents, whether or not the contents are relevant to the learning objectives, and the quality of teaching materials before being tested on students / students. After validating the product by the expert, then the product is revised to the errors that have been found. Data collection instruments in this evaluation used a questionnaire.

\section{b. Small Group Trials}

Evaluate a small group to find out the feasibility of digital learning media on the distribution system of electricity in new and renewable energy power plants by selecting 10 (ten) of electrical engineering students who have taken the subject matter contained in the competency standards of Renewable Energy courses. Through this trial we can know the level of ease of the material to be understood, systematic and interesting digital learning media and identify problems that may arise. Data collection instruments in this evaluation used a questionnaire.

\section{c. Large Group Trial}

Large group trials were conducted to determine the feasibility of instructional media that had been made by involving 33 students in electrical engineering. The purpose of this evaluation is to determine the feasibility of the product. Data collection instruments in this evaluation used a questionnaire.

\section{Data Collection Instruments}

The evaluation instrument for testing the validity / feasibility of teaching materials uses a questionnaire. Teaching material feasibility test questionnaire contains material assessment and learning media assessment. Before being used, the questionnaire validation of teaching materials was validated by the research supervisors. Questionnaire grids to assess the suitability of material guided by the 2006 National Education Standards Agency (BSNP). 
material content; (2) aspects of the feasibility of presenting the material; and (3) aspects of the feasibility of the material discussion. Table 1 lists the criteria for each aspect assessed.
To assess the appropriateness of teaching material material, 3 (three) aspects of the assessment are guided by the BSNP in 2006, namely: (1) Aspect of the appropriateness of

Table I. Material Feasibility Instruments

\begin{tabular}{|c|c|c|}
\hline Aspect & Criteria & Source \\
\hline $\begin{array}{l}\text { Aspect of } \\
\text { Source } \\
\text { Criteria }\end{array}$ & $\begin{array}{l}\text { Scope of material } \\
\text { Material Accuracy } \\
\text { Updated Material }\end{array}$ & $\begin{array}{l}\text { BSNP } \\
(2006)\end{array}$ \\
\hline $\begin{array}{l}\text { Aspect of } \\
\text { Eligibility of } \\
\text { Content }\end{array}$ & $\begin{array}{l}\text { Encourage curiosity } \\
\text { Presentation techniques Presentation } \\
\text { Aspects } \\
\text { Supporting presentation }\end{array}$ & $\begin{array}{l}\text { BSNP } \\
\text { (2006) }\end{array}$ \\
\hline $\begin{array}{l}\text { Aspects of } \\
\text { Linguistic } \\
\text { Linguistics }\end{array}$ & $\begin{array}{l}\text { Communicative } \\
\text { Coherence }\end{array}$ & $\begin{array}{l}\text { BSNP } \\
\text { (2006) }\end{array}$ \\
\hline
\end{tabular}

Material and media assessment instrument lattices are used as guidelines for the preparation of the research questionnaire. Through the research questionnaire that will be filled in by validator I, validator II, students of small group trial subjects and large group trial students can be identified errors from teaching materials that have been developed. Thus it can correct errors so that the teaching material that researchers develop can be used for learning activities in the New and Renewable Energy course.

The aspects assessed in the media feasibility assessment consist of: (1) software feasibility aspects; (2) aspects of learning design; and (3) aspects of visual communication. Questionnaire grids to assess the feasibility of instructional media according to Wahono (2006) are shown in Table 2.

\begin{tabular}{|c|c|c|}
\hline Aspect & Criterion & Source \\
\hline $\begin{array}{l}\text { Sofrtware } \\
\text { feasibillity }\end{array}$ & $\begin{array}{l}\text { - Usabillity } \\
\text { - Appropriate application type selection / } \\
\text { - } \text { - Comptware / tool } \\
\text { - User friendly. } \\
\text { - User manual explained }\end{array}$ & $\begin{array}{l}\text { Wahono } \\
\text { (2006) }\end{array}$ \\
\hline $\begin{array}{l}\text { Learning } \\
\text { design Aspect }\end{array}$ & $\begin{array}{l}\text { - Curriculum relevance } \\
\text { - Contextual } \\
\text { - Suitability of the material with the } \\
\text { learning objectives. } \\
\text { - Sistematic } \\
\text { questity of material discussion, sample } \\
\text { Consistent }\end{array}$ & $\begin{array}{l}\text { Wahono } \\
\text { (2006) }\end{array}$ \\
\hline $\begin{array}{l}\text { Communicati } \\
\text { on visual } \\
\text { aspect }\end{array}$ & $\begin{array}{l}\text { - Simple. } \\
\text { - Visual (layout design, typography, } \\
\text { colour). } \\
\text { - Communicative navigation }\end{array}$ & $\begin{array}{l}\text { Wahono } \\
\text { (2006) }\end{array}$ \\
\hline
\end{tabular}

The questionnaire using 4 (four) assessment levels according to a Likert scale. 4: Excelent, 3: Good, 2: Fair, 1:Bad (Sugiyono, 2016: 135). 


\section{Data Analysis}

The type of data obtained from this virtual laboratory development research is in the form of qualitative and quantitative data. Qualitative data are in the form of responses, comments, criticisms, suggestions and recommendations about virtual laboratories by validator I, validator II and students of the test subject written in the suggestion box on the final sheet questionnaire validation of teaching materials. While quantitative data were obtained from questionnaire scores given by subjects testing. To determine the feasibility of a virtual laboratory developed by conducting an evaluation or trial.

\section{DISCUSSION RESULT}

\section{Product Manufacture Results}

The results of this product development are digital media and simulation of Renewable Energy courses in electrical engineering department undergraduate students. Topics covered in this teaching material are: (a) new on-grid renewable electricity distribution system; (b) off-grid renewable electricity distribution systems; (c) new hybrid renewable electric energy distribution system on grid; and (d) a new off-grid hybrid renewable electricity distribution system. Digital learning media that are developed files with .exe extension that can be used as teaching material both in lectures and used as a means of independent learning.

\section{Display of Digital Learning Media Interfaces \\ a. Home page}

This page contains general information related to learning media developed in the form of time markers, learning media titles, university logos and media navigation initial instructions. In addition there are several navigation icons to operate learning media such as menu icons to access various contents contained in digital learning media, windows icons to set the size of digital learning media, close icons to close digital learning media programs, and navigation icons to manage media accompaniment music digital learning.

\section{b. Side Slide Menu}

Side slide menu is a menu that will appear from the side of the digital learning media layer when the menu navigation button is pressed. The menus include the homepage menu, guides, competencies, materials, simulations, evaluations and developer profiles.

\section{c. Guide page}

This page contains a quick guide to the functions of several icons contained in digital learning media so that it will facilitate users in running learning media applications. In addition there are also usage guidelines for students and lecturers which are used as a user guide when using digital learning media.

\section{d. Competency page}

The competency page contains information on the expertise competencies that will be achieved using this digital learning media. Apart from competency expertise, there are also indicators and learning objectives using this digital learning media. Indicator and destination page can be seen by pressing the right arrow direction icon on the right side of the digital learning media window layer.

\section{e. Material Pages}

When entering the material page, users of digital learning media will be treated to a choice of material about new and renewable electrical energy distribution systems. Some choices of material presented are: (1) Introduction, inside there is basic material about PLTS installation planning; (2) PLTS Off Grid System; (3) PLTS On Grid System; (4) PLT Hybrid Off Grid System; and (5) PLT Hybrid Off Grid System. The material to be discussed in digital learning media has been adjusted to the objectives to be achieved in learning by using this digital learning media.

\section{f. Simulation page}

The simulation page contains a simulation implementation guide for each material learned on digital learning media using the ETAP 12.6.0 application. Presentation of simulation guidance material is carried out in stages, at each stage the guidance provided will be increasingly reduced and limited. This is intended so that each student continues on the next practicum, students are forced to think and train themselves to operate the ETAP 12.6.0 application. In addition to guidelines in conducting simulations, there are also exercises so that students better understand the material being studied.

\section{g. Evaluation page}

On the opening of the evaluation page there is a brief information about the evaluation that will be done and a button to start working on it. The evaluation page consists of 10 (ten) multiple choice questions, each of which is worth 10 points. If students answer the questions correctly, then automatically the value column will increase by 10 points and will not change if the answer given is wrong.

\section{Digital Media and Simulation Feasibility Test Results}

Presentation of data in this research consists of data to see how feasible digital learning media and simulation from expert validation, small group trial and large group implementation had been shown as following descriptions with a percentage graph in Figure 3. 


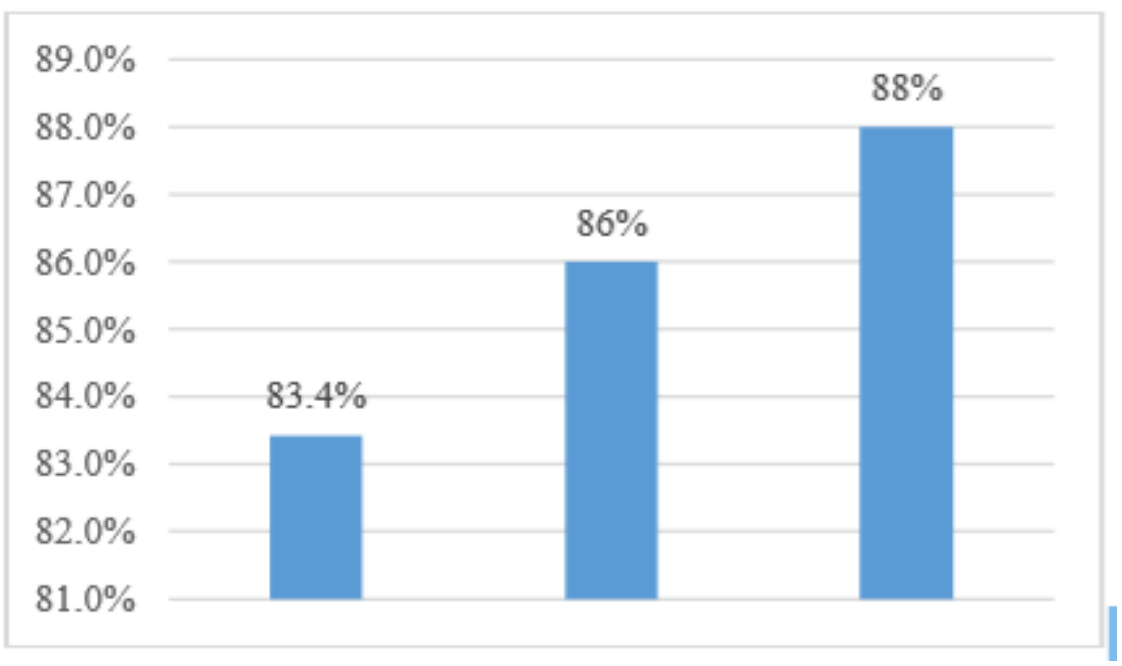

Figure 3. Feasibility Validation of Digital Media and Simulation

\section{CONCLUSION}

The research and development of Digital Media and simulations uses the ADDIE model has 5 (five) stages, namely: (1) Analysis; (2) Design; (3) Develop; (4) Implement; and (5) Evaluate. Based on the results of the due diligence test by validator I and II the media is declared valid but needs to be revised with a feasibility level of $83.4 \%$. Whereas based on the results of small group trials, digital learning media were declared $86 \%$ valid or feasible without any revision. And finally for the results of a large group of digital learning media implementation declared valid $88 \%$ or feasible without any revisions. So the conclusion is learning media is feasible to be implemented in learning.

\section{REFERENCES}

[1] PPKI UM 2017. Pedoman Penulisan Karya Tulis Ilmiah Malang. Malang: Universitas Negeri Malang.

[2] Anonim. 2016. Statistik Energi Baru Terbarukan dan Konversi Energi (EBTKE). Jakarta: ESDM.

[3] Anonim. 2018. Rencana Usaha Penyediaan Tenaga Listrik (RUPTL). Jakarta: PT. PLN.

[4] Anonim, 2018. Energi Baru dan Terbarukan Untuk Menjaga Bauran Energi Pembangkit. Jakarta: ESDM.

[5] Kamus Besar Bahasa Indonesia (KBBI). (Online), (http://kbbi-webid.cdn.ampproject.org/), diakses 20 Desember 2019.

[6] Smith, S dan Sandra K. 2008. Assessing and Addressing Student Science Ideas. Jurna Pendidikan. (http://ro.ecu.au/ajte/vol45/iss4/4), diakses Januari 2019.

[7] Prahasta Rezky Prima, Penangsang Ketut \& Ketut Aryani Ni. 2016. Studi Analisa Stabilitas Transien Sistem Jawa-Madura-Bali (Jamali) 500 kV Setelah Masuknya Pembangkit Paiton 1000 MW Pada Tahun 2021. Surabaya: Institut Teknologi Surabaya.

[8] Sugiyono. 2016. Metode Penelitian Pendidikan Kuantitatif, Kualitatif dan R\&D. Bandung: Alfabeta.

[9] Sukmadinata, S. 2012. Metode Penelitian Pendidikan. Bandung: PT. Remaja Rosdakarya.

[10] Pribadi, B. 2009. Model Desain Sistem Pembelajaran. Jakarta: PT. Dian Rakyatakbar.

[11] Raiser, Rober A \& Dempsey, John. 2012. Trends and Issues in Instructional Design and Technology. Inggris: Pearson Education.

[12] Anderson \& Krathwohl, 2001. A Taxonomy for Learnings, Teaching, and Assessing: a Revision of Bloom's Taxonomy of Educational Objectives. Inggris: Longman.

[13] Arsyad, Azhar. 2014. Media Pembelajaran. Jakarta: Raja Grafindo Persada.

[14] Hasan, S. 2006. Analisis Perakitan Trainer Unit Berdasarkan Aplikasi Konsep Refrigasi pada Matakuliah Sistem Pendingin (Bahan Kuliah). Bandung: Universitas Pendidikan Indonesia.

[15] Sadiman, S \& Rahardjo, R. 2010. Media Pendidikan, Pengertian, Pengembangan dan Pemanfaatannya. Jakarta: PT. Raja Grafindo Persada. 
[16] Imran. 2012. Ayo Manfaatkan Laboratorium Virtual. (Online), (http://mazguru.wordpress.com/2012/04/19/ayomanfaatkanlaboratorium-virtual/), diakses 9 Januari 2019.

[17] Arsyad, Azhar. 2009. Media Pembelajaran. Jakarta: Raja Grafindo Persada.

[18] Wiryanto. 2014. Representasi Siswa Sekolah Dasar Dalam Pemahaman Konsep Pecahan. Jurnal Pendidikan Teknik Elektro UNIMED, Vol, 03 No 3, pp 593-603.

[19] Sentyasa, I Wayan. 2007. Landasan Konseptual Media Pembelajaran. Prosiding Workshop Media Pembelajaran. Bali: Universitas Pendidikan Ganesha.

[20] Made, Wena. 2011. Strategi Pembelajaran Inovatif Kontemporer: Suatu Tujuan Konseptual Operasional. Jakarta: Bumi Aksara
[21] Munir. 2012. Multimedia, Konsep dan Aplikasi dalam Pendidikan. Bandung: Alfabeta.

[22] Anonim. 2014. Katalog Jurusan Teknik Elektro Universitas Negeri Malang. Malang, Universitas Negeri Malang.

[23] Wahono RS. 2006. Aspek dan Kriteria Media Pembelajaran. (Online), (http://romistriawahono.net), diakses 9 Januari 2019.

[24] Akbar, S. 2013. Instrument Perangkat Pembelajaran. Bandung: PT. Remaja Rosdakarya.

[25] Daryanto \& Aris Dwicahyono, 2014. Pengembangan Perangkat Pembelajaran (Silabus, RPP, PHB, Bahan Ajar). Yogyakarta: Gava Media.

[26] Depdikbud, 2008. Panduan Pengembangan Bahan Ajar. Dirjen Diknasmen Direktorat Pembinaan SMA. 